\title{
Human dignity and education - A Protestant view
}

\begin{tabular}{|c|c|}
\hline \multicolumn{2}{|c|}{$\begin{array}{l}\text { Author: } \\
\text { Friedrich Schweitzer }{ }^{1,2}\end{array}$} \\
\hline \multicolumn{2}{|c|}{$\begin{array}{l}\text { Affiliations: } \\
{ }^{1} \text { Professor of Practical } \\
\text { Theology/Religious } \\
\text { Education, Faculty of } \\
\text { Protestant Theology, } \\
\text { University of Tübingen, } \\
\text { Germany }\end{array}$} \\
\hline \multicolumn{2}{|c|}{$\begin{array}{l}{ }^{2} \text { Department of Practical } \\
\text { Theology, Faculty of } \\
\text { Theology, University of } \\
\text { Pretoria, South Africa }\end{array}$} \\
\hline \multicolumn{2}{|c|}{$\begin{array}{l}\text { Project leader: Yolanda Dreyer } \\
\text { Project number: } 2546930\end{array}$} \\
\hline \multicolumn{2}{|c|}{$\begin{array}{l}\text { Description: } \\
\text { Prof. Dr Friedrich Schweitzer } \\
\text { is participating in the } \\
\text { research project 'Gender } \\
\text { Studies and Practical } \\
\text { Theology Theory Formation', } \\
\text { directed by Prof. Dr Yolanda } \\
\text { Dreyer, Department of } \\
\text { Practical Theology, Faculty of } \\
\text { Theology, University of } \\
\text { Pretoria, South Africa. }\end{array}$} \\
\hline \multicolumn{2}{|c|}{$\begin{array}{l}\text { Corresponding author: } \\
\text { Friedrich Schweitzer, } \\
\text { friedrich.schweitzer@ } \\
\text { uni-tuebingen.de }\end{array}$} \\
\hline \multicolumn{2}{|c|}{$\begin{array}{l}\text { Dates: } \\
\text { Received: } 12 \text { Apr. } 2016 \\
\text { Accepted: } 28 \text { May } 2016 \\
\text { Published: } 29 \text { Aug. } 2016\end{array}$} \\
\hline \multicolumn{2}{|c|}{$\begin{array}{l}\text { How to cite this article: } \\
\text { Schweitzer, F., 2016, 'Human } \\
\text { dignity and education - } \\
\text { A protestant view', HTS } \\
\text { Teologiese Studies/ } \\
\text { Theological Studies 72(4), } \\
\text { a3436. http://dx.doi. } \\
\text { org/10.4102/hts.v72i4.3436 }\end{array}$} \\
\hline \multicolumn{2}{|c|}{$\begin{array}{l}\text { Copyright: } \\
\text { (C) 2016. The Authors. } \\
\text { Licensee: AOSIS. This } \\
\text { is licensed under the } \\
\text { Creative Commons } \\
\text { Attribution License. }\end{array}$} \\
\hline \multicolumn{2}{|l|}{ Read online: } \\
\hline 口iritg & $\begin{array}{l}\text { Scan this QR } \\
\text { code with your } \\
\text { smart phone or } \\
\text { mobile device } \\
\text { to read online. }\end{array}$ \\
\hline
\end{tabular}

Taking current discussions on the relationship between human dignity as a human right and education as his starting point the author pursues the possibility of interpreting this relationship from a Protestant perspective based on the biblical understanding of the likeness of God. Since this understanding has not been at the centre of the majority view in Protestant educational thinking the author tries to uncover a minority tradition that has made the likeness of God the basis of education (Melanchthon, Comenius, and others). In another step, the author describes four foundational perspectives for making the likeness of God and human dignity the basis for education today, addressing education beyond utilitarianism, justice in education and education for justice, interreligious education and special commitment to children's rights. In all four respects Protestantism can make important contributions but there is also a need for the renewal of Protestantism's understanding of education in light of future challenges.

\section{Introduction}

To view education as a question of human dignity has become a widespread understanding and concern. More precisely, this means that the right to education is considered a basic human right. The reference to human dignity is firmly rooted in the human rights tradition. Already in its first sentence the United Nations' Universal Declaration of Human Rights refers to the 'inherent dignity' of 'all members of the human family'. Article 1 states: 'All human beings are born free and equal in dignity and rights'. In the perspective of this declaration, this implies a clear connection to education, as expressed explicitly in Article 26.1: 'Everyone has the right to education'. The right to education appears to be a direct and unquestionable implication of human dignity.

Human dignity is also considered a core value in today's Protestant theology. In this case, however, the foundational reference is not to human rights as the basis of this dignity. Instead, human dignity is itself seen as founded in the human's likeness of God, in the sense of Genesis 1:26f. In other words, this dignity is the special gift from God who created the humans as special beings in God's own likeness. Then God said, 'Let us make man in our image, after our likeness' (KJV). Human rights then are considered the outgrowth of this biblical understanding.

In recent times in Germany where I am working, the Protestant Church has strongly emphasised the Christian roots of human dignity as a human right, even viewing the Christian understanding of human dignity as the core of the Protestant contribution not only to German society but also to basic European values on the whole. In December 2006, on the occasion of the German presidency of the Council of the European Union, the Council of the Evangelical Church in Germany emphasised the central position of human dignity in the Protestant understanding, calling it the 'foundation' of 'European basic values' (EKD 2006). This is explained in the following manner: 'To shape European politics according to these values means to make the criteria of human dignity and of a corresponding understanding of the human being its guideline'. Furthermore, the link between human dignity and education is emphasised by the Church in this context as well: 'It is part of this [understanding; F.S.] to make chances for education available to everyone and to realise justice as enabling the young generation (Befähigungsgerechtigkeit)'. In this view, it can also not be permitted that the 'right to education' is 'reduced to the acquisition of work-related competencies'. According to this view, the reference to human dignity equals the demand for an education that makes human needs and interests in the sense of the individual person a decisive criteria for education, instead of, for example, economic constraints.

The Church's argument appears convincing and timely. It makes sense that the Church insists on the need for not basing education only on economic demands, be it of one's own country or of an international body like the European Union. Yet it should not be overlooked that the emphasis of human dignity is not in line with the Protestant tradition in education, at least not in terms of the 
majority tradition. While it is certainly true that the Protestant tradition has put a lot of emphasis on education from its beginnings in the 16th century, human dignity was not the starting point for the Protestant conception of the tasks of education. Instead, in many cases, it was the fallen nature of the humans that made education necessary in order to work against the consequences of $\sin$.

Given this background and especially the tension between the long-term Protestant tradition on the one hand and current statements by churches on the other, it is surprising that the relationship between human dignity and education has not received more attention in recent years. The present article which draws on my own work concerning human dignity and education as well as the renewal of Protestant educational thinking in a number of respects will address this lacuna by focusing on a Protestant theological understanding of the relationship between human dignity, the likeness of God, and education (cf. Schweitzer 2011, 2014a, 2014b, 2016; given the general nature of the present text I have limited the number of references to a minimum further references as well as more detailed accounts can be found in these publications). I will first try to unearth what can be called a minority tradition in Protestantism that indeed used the likeness of God as the starting point of their understanding of Christian education. Moreover, I will also attempt to show why this approach is of importance today, not only for Protestantism itself but also for society at large.

As will be obvious from the following, I am writing this article as a German Protestant (religious) educator and practical theologian, working at a faculty of theology. More than I can show in this article I am also indebted to international cooperation with colleagues from many other countries, for example, South Africa. In this respect I should also mention that I am currently working on a joint-study on the future of Protestant education together with two colleagues from Korea (Hyun-Sook Kim, Seoul) and the United States (Richard R. Osmer, Princeton).

\section{(Re-)Discovering the link between human dignity and education in the Protestant tradition}

As mentioned above, the reference to human dignity was not the starting point for the majority tradition in Protestant educational thinking. Most of all for Martin Luther, the need for education arises much more from the fallen nature of the human and from the sin following from it as well as from the need to prevent the negative individual as well as social consequences of sin (cf. Schweitzer 2011:19-23). This also explains why the human's likeness of God was not his starting point for his ideas on education. According to Luther, education is not about salvation, and it cannot be the task of education to restore the humans to their likeness of God. Given the state of fallen nature, education cannot and should not claim to take over such a task. For Luther, education is a 'wordly affair', part of God's worldly governance as opposed to God's spiritual governance, as Luther describes it in terms of his teaching of the two kingdoms (cf. Luther 1982a, 1982b). To restore humans as images of God is beyond the reach of the worldly governance to which education belongs. This understanding has been very influential in the Protestant tradition, especially within Lutheranism. Given Luther's farreaching influence on Protestant educational thinking, it can certainly be called the majority tradition.

In its broad use as it is found, for example, in the statements from the Evangelical Church in Germany today quoted in the introduction, the reference to the likeness of God as foundation for a Protestant understanding of education is still rather new then. Yet there were at least two important and also most influential representatives of the Protestant tradition in education who actually made the likeness of God one of their decisive starting points in education. The first was Philipp Melanchthon, the other Johann Amos Comenius.

For Luther's close colleague and personal friend Melanchthon, it was of prime importance that education must do justice both to the needs of society as well as to the needs of the individual. He expected education to help overcome barbarianism by making people moral. In this context, he refers to the human in his (today, we would of course add 'her') likeness of God as the basis for their calling: 'The human should be such an image of God that he perceive and understand the similarity'. (Melanchthon 1989:81) For Melanchthon, the 'strongest similarity is the concordance in wisdom and justice as it can only be present with a reasonable being' (Melanchthon 1989:81). In other words, Melanchthon understood the humans' likeness of God to give them an ultimate direction in life. Wisdom and justice are at the core of this vision which, this should also not be overlooked, is in line with human reason. Moreover, the educated human should have gained insight into the 'similarity' implied by their likeness of God.

At the same time, Melanchthon does not overlook the influence of human sin and its effects on human life. Yet more than, for example, Luther, Melanchthon bases his understanding on the renewal that has already taken place in Christ. Fallen human nature is not the only starting point for him. The renewal (renovatio) of the likeness of God becomes more important. This does not mean, however, that education could take over the task of this renewal. Only the divine Spirit can do this which is why the renewal necessarily remains unfinished on earth: 'The likeness will only be complete when, in the heavenly church, God will be all in all'. (Melanchthon 1989:86) This caveat should certainly not be overlooked. Melanchthon was far from idealising the human or from overestimating education by turning it into some kind of salvific activity. In this respect, his views are close to those of Luther. Yet, Melanchthon's emphasis of renewal clearly adds a different perspective to his educational thinking by making the likeness of God an ultimate guideline for education. 
Melanchthon's arguments show that the likeness of God and the calling given to the human through it, actually were present with the Reformers in the 16th century and that these ideas could act as a basic motivation for education even then. In the 17th century, however, the European theologian and educational philosopher Johann Amos Comenius took up this line of thinking in order to emphasise it even more by making the understanding of the human's creation in the likeness of God the starting point for his whole understanding of education. This is quite remarkable in that Comenius was one of the very first Protestant thinkers to develop a comprehensive understanding of education. Together with his ecumenical openness and his global thinking, this makes him a true classic of education, not only within the Protestant tradition but for the philosophy of education in general. Moreover, it means that there is a close connection between the development of a systematic Protestant approach to education on the one hand and the likeness of God or, to use the later term, human dignity on the other.

In his most important work on education - the Pampaedia which was published not before its rediscovery in the second half of the 20th century - Comenius expresses his understanding of education in relationship to Genesis 1:26f. Education is viewed as taking on its tasks from the faith in creation. For Comenius, God should be able to really achieve his 'aim intended with the creation of the human' (Comenius 1965:24). In other words, education becomes the continuation of God's creative activity. Through this, 'complete wisdom' is considered an aim of education. 'Since all humans are created in the image of the most wise God, we must make it our concern that the ectypal image responds to its archetypal image' (Comenius 1965:26). Again, just like for Melanchthon, wisdom is an important part of education envisioned by Comenius. Since Melanchthon was part of the Reformed tradition one may also think here of Calvin's understanding of the human's renewal in Christ for which intelligentia plays a key role (Calvin 1874:130).

Also just like Melanchthon (and in a different context not related to education, also Calvin), but in a more radical manner, Comenius concentrates on the renewal of the human that has occurred in Christ. This is why he is convinced that education has to focus on human renewal in correspondence to the likeness of God. In the case of Comenius, the balance between the redemptive influence of Christ and the limitations to redemption in this world clearly has moved towards higher hopes for what education can achieve already today. For him, it is the task of education to bring the humans in line with their likeness of God.

Moreover, Comenius clearly wants all humans included in the task of education, independently of their situation or social background. This gives his understanding of the likeness of God a revolutionary meaning, especially in 17th century, when there were no democracies in view in Europe: 'In brief, where God did not discriminate (discrimen non posuit), no one should discriminate' (Comenius 1965:30). Education should include each and everyone (omnes) - this is the pedagogical creed of all of Comenius' writings.
It is also easy to see that for Comenius the understanding of the likeness of God comes quite close to what was later called human dignity, for example, in terms of human rights. His emphasis on what each human being deserves or is entitled to as one of God's creatures has implications that are quite similar to the 'inherent dignity' of 'all members of the human family' as the Universal Declaration of Human Rights puts it. Or, to quote the American Declaration of Independence from 1776: 'We hold these truths to be self-evident, that all men are created equal, that they are endowed by their Creator with certain unalienable Rights, that among these are Life, Liberty and the pursuit of Happiness'. Here, the close connection between God the creator and the 'unalienable rights' of all human beings is expressed directly. It is no coincidence although not in the sense of a direct historical link - that even the wording is rather close to that of Comenius.

It is not my intention here to write a history of Protestant education and of the role that the understanding of the likeness of God has played for it (cf. Schweitzer 2011:17-50). Yet, at least two additional strands of tradition must be mentioned in the present context. They also show the connection between the understanding of the likeness of God and education, in this case beyond the explicitly Protestant tradition. The German term Bildung (education in the sense of paideia), which until today has played a key role for the German understanding of the aims of education, was coined in the 14th century in connection with the idea of the likeness of God (cf. Schweitzer 2014a). One of the first - and possibly even the very first - to use this new German term was the mystic Master Eckhart (cf. for example, Meister Eckhart 1963:471-497). He combined the Christian view of the human as the image of God with neo-Platonic views of imago, in terms of archetype and effigy. At the same time, he understands education as a theological or religious process, following 2 Corinthians 3:18 in the sense of a transformation in Christ:

And we all, with unveiled face, beholding the glory of the Lord, are being changed into his likeness from one degree of glory to another; for this comes from the Lord who is the Spirit' (KJV).

The German term Bildung contains the word Bild = image/ imago which explains the rich connotations of this concept, although most people today are not aware of its Christian roots in mysticism.

In the 18th century, when the philosophy of education became more widespread and also more independent from theology, at least the philosophers of education of that time were clearly still aware of the connection between education and the likeness of God. For this reason, this connection remained influential, especially with Protestant thinkers like Johann Gottfried Herder. Herder makes the likeness of God his basic model for his understanding of the ultimate human purpose and, through this, also the ultimate end of education (cf. Herder 1968). The philosophies developed by Herder and his contemporaries under the influence of Protestantism remained influential, even if later philosophers often took them up for reasons that had little to do with explicitly 
Protestant ideas. This is one of the reasons why Protestantism could become so influential in German education - not so much through theology or theological teachings but through educational concepts, ideas and ideals impregnated by Protestantism even when they appeared non-religious (cf. e.g. Koselleck 1990; Tröhler 2011).

Since it is not my intention here to capture the history of Protestant education, however, I will not pursue its further developments in Modern Times. Instead I will now turn to a more systematic account of what I consider a Protestant understanding of human dignity in the sense of the likeness of God as a basis for education today.

\section{The likeness of God and human dignity as a basis for education: four foundational perspectives}

Although it could be shown above that the likeness of God as a starting point for education was indeed present in Protestantism from early on and that even highly influential Protestant theologians and philosophers of education entertained this understanding in the 17th and 18th century, it is still fair to say that, beyond these beginnings, this understanding has not been developed in detail. Yet, as whoever is involved in questions of education knows all too well, it is not enough to invoke even the very best ideals or theological ideas unless one can show what they mean for concrete educational practice. This is why I will develop and discuss, at least to some degree, four foundational perspectives which can make the meaning of a Protestant understanding of the likeness of God and human dignity the basis for education more concrete.

These perspectives are chosen for three reasons: Firstly, they deserve a central position for theological reasons and secondly, they refer to central directions for the renewal of Protestant thinking in education today and thirdly, they are apt to show that a Protestant understanding of education can be of importance beyond theology and the church as well. This last reason deserves special attention. At least in Europe, the influence of Protestantism appears to be waning. Secularisation and, even more, cultural and religious pluralisation are working against religious influences on education altogether. Religions are often considered divisive and as a topic that is better left to the private realm. Consequently, there is a growing need for Protestantism - as well as for other denominations and religions - to demonstrate the plausibility of their educational views beyond their own membership.

\section{The need for renewal: Education beyond utilitarian thinking}

Education certainly belongs to the fields which are often considered in need of renewal. In today's political debates on education, this need is first of all related to economic development and to the competitive demands of international markets. The PISA studies (Program for International Student Assessment) are one of the most visible and influential examples in this respect. When these studies started, the OECD published its understanding in a document called 'Knowledge and Skills for Life' (OECD 2001) which discusses the criteria for what it means 'to succeed in life'. For the OECD, the answer is brief: 'labour market success and earnings' or, even shorter, 'better jobs' and 'higher salaries' (OECD 2001:19-20). This definition of 'success' most likely expresses the motives of many people today, especially in politics.

From a theological point of view, the importance of an individual's 'labour market success and earnings' should not be denied. Education should indeed contribute to preparing young people for successful participation in the labour market. Yet, the question must be posed if an education that makes this kind of success the exclusive goal of education is even feasible. Would it not necessarily defeat itself because the human beings who are to be educated must also be supported in their personal development, even if only in order to make reasonable use of economic insights and technical skills? In other words, the demand to make 'better jobs' and 'higher salaries' the exclusive guiding aim of education becomes self-contradictory. This can be called the dilemma of any strictly utilitarian understanding of education: In order to achieve its end, even utilitarianism must go beyond its demand-oriented criteria.

In the past, religion was often expected to provide broader and more substantial meaning systems as a basis for education by offering normative visions of a good and Godrespecting life. Given the multiple influences of secularisation and religious pluralisation in many societies around the world, most educational institutions have given up on religion as a source of meaning that could be normative for all pupils and teachers. Instead, they use terms like 'excellence' as guiding norms, yet often without becoming more specific about the criteria by which this excellence can be determined. From its Latin root, the term means something like 'to be better than others'. Yet it does not state in what respect. In other words, the reference to excellence does not mean much unless one specifies in what direction pupils should excel.

This is why human dignity as a norm or value recommends itself for giving orientation to education. Human dignity can be viewed as a guiding norm or value for the understanding what terms like excellence should mean. Yet the challenge mentioned above that the reference to educational ideals remains abstract vis-à-vis the actual practice of education, may also apply to human dignity. Even if human dignity is rooted in the understanding of human rights - and in this sense is often mentioned in educational documents - this does not seem to leave much of an impression on the everyday life of educational institutions. There are at least two reasons for this. Firstly, human rights are necessarily abstract. Otherwise they could not be expected to be accepted 
by all people. Yet it always remains an open question what they actually mean in everyday life or, in the present context, for the actual practice of teaching and learning. Secondly, abstract rights do not imply the power to motivate people for working towards their implementation. Declarations of human rights are a good example for this. While there may be very few objections to these rights, familiarity with them as such does not make people act accordingly. Knowing the rights and respecting them or even be actively committed to their fulfilment clearly are different things.

It is in the relationship to the two problems of the abstract nature of human rights and their lack of motivating power that a religious or theological approach may become attractive again, presupposed that it can be made more concrete than an abstract reference to universalist principles. A first step in this direction can be taken by looking into the relationship between the likeness of God and the understanding of justice, especially in education.

\section{Justice in education - education for justice}

Justice is of course a central topic throughout the Bible. It can therefore be called a guiding norm or value for all Christian ethics. Yet justice has also become a guiding norm of secular ethics, especially in terms of equal treatment of all people and, in general, in terms of the principle of equality itself. What does the Protestant tradition have to add to this, and what understanding should guide Protestant educational thinking today?

The statement from the Evangelical Church in Germany quoted above makes special reference to the so-called capability approach that aims for individual enablement as criteria of justice: 'It is part of this [understanding; F.S.] to make chances for education available to everyone and to realise justice as enabling the young generation (Befähigungsgerechtigkeit)'. This approach was developed by Martha Nussbaum (Nussbaum 2006) and Amartya Sen (Sen 2009) in philosophy, not in relationship to education but in a general sense. Yet it also fits very well with educational contexts as Nussbaum herself has shown in later publications (Nussbaum 2011).

The disappointing and discouraging outcome of what can probably be called one of the most determined efforts to achieve equality in education - the educational reforms undertaken in many countries of the Western world in the 1960s - was that these reforms obviously did not reach their aim. The inequality in education and in educational success that had motivated these reforms, did not disappear, in spite of all efforts to provide equal chances to all people (cf. Jencks 1972). More recently, the international PISA studies point into the same direction. Among others in my own country Germany - there is still a very strong connection between how children enter school and how they leave it. In other words, disadvantageous experiences in childhood are not compensated or overcome by what school does for the children.
Although there are certainly many factors involved that contribute to an explanation of such effects, the capability approach is of special importance in this respect. Its basic argument is that different people have different needs because they have different abilities. To offer them 'equal chances' will therefore not result in more equality but, quite the opposite, will lead to more inequality. Only the able ones can make use of the chances offered to them. Unless schools are prepared to actively respond to such individual differences between different children, the pupils will never experience justice in the sense of equal treatment in the light of who they really are and what they can really do. Most of all, schools will continue to miss the aim of achieving equal participation in culture and society for as many of the children and youth as possible.

Nussbaum and Sen do not call upon religion or theology for their interpretation of the connection between justice and capability. Yet it seems obvious that the Protestant understanding of justice and of divine justification could indeed work as powerful support for their views. One of Luther's core insights refers to exactly this - that God's justice does not mean that each human will be judged based on the law given to them by God, for example, in the shape of the Ten Commandments. For no one could be expected to be able to justify himself or herself in relationship to this law. All have failed against it - 'None is righteous, no, not one' (Romans 3:10). God's justice means redemptive love that is not based on retribution but on the rescue and restoration of the humans. This Protestant understanding of justice clearly relativises any understanding that is based on the logic of 'equal chances' alone.

The teaching of the two kingdoms characteristic of the Lutheran tradition with its distinction between the wordly realm and the spiritual realm has often worked against the application of this understanding of redemptive or restorative justice to education. Education was considered a 'worldly affair' while God's justice in the sense of the justification of the sinner was seen as applying only to the spiritual realm. Concerning this traditional understanding, focusing on justice as enabling or empowering people also means a renewal for the Protestant tradition in education.

So far, this section was about justice in education - justice to be done to children and youth. Yet this is only the one side of the coin. The other side of this coin in Protestant educational thinking refers to education for justice - the justice to be done by children and youth, including in their later life, and therefore to justice as a basic orientation to be acquired in education. It is important to note that education for justice entails four dimensions and that these dimensions make its understanding distinctive in terms of Protestantism.

Firstly, there is the dimension of making sure that justice will really be understood as a core normative orientation for education. This dimension is not distinctive of Protestantism. Clearly, many individuals or groups that are convinced of the need for a better world would be in support of this orientation. 
Secondly, the relationship to a God who treats humans in a just manner, accepting them and restoring them to their true selves not because of their achievements but out of redemptive love, can operate as an existential motivation for one's own commitment to justice. This motivation for a loving justice probably can be called the most distinctively Protestant dimension of education for justice in that it clearly corresponds to the Protestant teaching of justification by faith and grace.

Thirdly, Protestant education has always emphasised the need for each individual person to understand what faith is about. This implies that it is not enough if educators are aware of the interconnection between divine justification and love on the one hand and human commitment to justice on the other. Instead, it is an indispensable task of religious education to make this understanding transparent for each and everyone.

Fourthly, all education for justice has to worry about providing enough motive for people to adopt justice as a guiding principle for their living and acting. Insight obviously is not enough in order to achieve this aim. The specific relationship to God described as the second dimension above is one of the motivations to be considered in this context. Another motivation is related to the influence of a Christian ethos that can be distinguished from Christian ethics. Ethics means teaching and reflecting on justice, and as such it is also indispensable. In terms of education, however, it presupposes the experience of justice in the sense of justice lived by a community. This is exactly what the term ethos stands for the lived form of Christian ethics. The concept of ethos refers to an order of a system of interaction that is characteristic of a certain group or institution. Families, congregations and groups that are trying to embody such an ethos clearly operate as carriers of education for justice.

At different times in history, justice can mean different things, at least in terms of the context to which it must apply. One context that is still in the process of emerging into Christian consciousness relates to other religions and therefore to the issue of religious tolerance.

\section{Education for a tolerant ethos: interreligious education}

The Protestant Reformers of the 16th century can hardly be called upon as models for interreligious education and openness. At that time, neither today's multireligious challenges nor the potentials and possibilities of interreligious dialogue were in view. So why should we think of the Protestant tradition in this respect?

Two arguments can play an important role for this context:

- According to contemporary Protestant theology, the Protestant understanding of faith offers far-reaching possibilities for identifying a religious basis for tolerance (cf., for example, Schwöbel 2003). At its core, this argument is again directly linked to the Protestant understanding of faith and of justification. If it is true that justification occurs exclusively by faith (sola fide) this implies that faith cannot be the expression of human willingness or any other doing of humans. Instead it is God's gift. Otherwise the idea of justification by faith alone would end up in self-contradictions. Yet, what Protestant Christians claim for themselves and for their faith, must also be applied to the faith of others. Consequently, even if this faith is different from the Christian faith, it must be tolerated - for the sake of Christian faith.

It is important to note that it is exactly this point where contemporary Protestant theology has come to conclusions that are different from the tradition. Most of the Protestant tradition, be it in theology or education, tended to limit tolerance to the parameters of an agreement about the faith. Beyond that, it was only the person that could be tolerated but not his or her faith. In today's understanding, this traditional distinction appears problematic. What does tolerance or respect for the person mean if it excludes the person's deepest convictions? Moreover, how can Protestants claim for their faith that it is a gift from God, without even taking into consideration the other person's understanding of his or her faith?

- Like many other attitudes, tolerance cannot be taught directly. While it is certainly possible to teach a theoretical understanding of tolerance, including good reasons for it, this may lead to more refined knowledge in this respect but it will not make a person more tolerant. In parallel to what was said about education for justice above, it makes sense to say that education for tolerance presupposes the experience of lived tolerance or of an ethos of tolerance. Both, religious groups or congregations as well as institutions should therefore develop and embody such an ethos that can shape attitudes much more than teaching at an exclusively cognitive level.

It would be difficult to claim that Protestantism has actually come to the point at which tolerance and openness for the faith of others and a tolerant ethos can be taken for granted. Again, I am referring to necessary future developments and tasks for Protestantism, but, at the same time, also to an important potential inherent in this tradition. This potential allows for orientations that avoid both, fundamentalist as well as relativistic tendencies.

Fundamentalism is excluded if the faith of the other is respected in parallel to one's own faith convictions. Yet this does not imply that religious truth is considered impossible which would be the relativistic conclusion.

Interreligious education certainly is a core task for the future, in society in general as well as for Protestantism in particular. An ethos of tolerance is the basis for this kind of education. In addition to this, there are specific educational presuppositions that, for the sake of space, cannot be explained in detail here (for a broader treatment of this question see Schweitzer 2014b). 


\section{Special commitment to children's rights}

The reference to children's rights belongs to the 20th century. The first public declaration of such rights was proclaimed in 1924 at Geneva by the League of Nations. Influential authors like the Polish-Jewish paediatrician and educator Janusz Korczak helped to establish the view that children have rights of their own and that these rights are not just a derivative or a part of parents' rights (cf. Korczak 2007). It took until 1989, however, before the United Nations, after having proclaimed a brief version in 1959, passed their now famous Convention on the Rights of the Child. Yet even today, education based on children's rights still is more of a plea than a reality, at least in most parts of the world.

Although the idea of children's rights emerged late in history and in spite of the observation that the full enactment of such rights has still not been achieved even today, it is important to realise that this idea has deep roots in the biblical tradition and especially in the New Testament (cf. Bunge 2001). For the Bible, children are a promise and a gift from God to be cherished from the beginning. The New Testament tells of the special appreciation Jesus had for children. According to Jesus, the kingdom of God belongs to children, adults have to receive it like a child, and they must become like children (Mk 10:13-16 par.).

These views are interpreted as a special attitude towards children that was quite different from the views common in other cultures of the time. They also became the starting point for a long tradition of special concern for children in the history of Christianity. From today's point of view, this tradition was certainly mixed - with better or worse consequences for children. Yet it definitely kept awake a certain awareness of the special Christian obligation for the children's good that fits well with the movement for children's rights in the 20th century.

Today, from a Protestant understanding, children - and in the meantime also adolescents who are not mentioned in the Bible because adolescence as we know it today was inexistent then - must be the starting point of education. Neither the needs of society nor the interests of institutions, including the church, can override this starting point.

That this demand is really taken seriously by the Protestant church and by theology can possibly best be judged from how religious education is conceptualised. In my own understanding, children are entitled to religion in the sense of having access to some kind of religious nurture and education (Schweitzer 2013). Children's right to religion is the basis for claims against educational institutions like kindergartens or schools as well against the state as the sponsor of such institutions. On their part, it establishes an obligation to make respective programs available to all children and parents who are interested in them. At the same time, however, the approach based on children's right to religion also implies norms and guidelines for religious education. It would be highly inconsistent to make children's right to religion one's starting point while not adhering to child-oriented methods of education.

\section{Perspectives for the future: an unfinished learning process}

The aim of this article was to (re-)discover the role of human dignity, understood as an expression of the likeness of God, within the Protestant tradition of educational thinking. Moreover, I tried to show why this approach is of importance today, not only for Protestantism itself but also for society at large. In pursuing this aim, however, it also turned out that making human dignity the starting point for Protestant educational thinking implies that both, Protestantism itself as well as society at large will have to be open to educational renewal in several respects.

More specifically this demand relates to all four aspects considered above - education beyond utilitarianism, justice in education and education for justice, interreligious education, and special commitment to children's rights. In each case the Protestant tradition has to be evaluated critically, from both perspectives, the perspective of contemporary and future demands on the one hand as well as the perspective of its original meaning that has not always been preserved, on the other. In this sense, making human dignity the starting point in Protestant educational thinking is still in progress, not a matter that would refer to the past but to the future.

This last point is even more true for society at large. While the connection between human dignity and education in terms of human rights has come to permeate many contemporary discussions, in education as well as in politics, it cannot be overlooked that the promise of human dignity is still unfulfilled. Many children, adolescents and adults do not have access to an education that is in line with the demands based on human rights. Moreover, the education that is available in many institutions does not do justice to these demands. The reference to human dignity and education therefore refers to a general learning process, not only for the church but for society altogether. To contribute to this process will be a major task for Protestantism in the future.

\section{Acknowledgements Competing interests}

The author declares that he has no financial or personal relationships which may have inappropriately influenced him in writing this article.

\section{References}

Bunge, M.J. (ed.), 2001, The child in Christian thought, Wm. B. Eerdemans Publishing Company, Grand Rapids, MI.

Calvin, I., 1874, in A. Tholuck (ed.), Institutio Christianae Religionis, Pars Prior, G Eichler, Berlin.

Comenius, J.A., 1965, in D. Tschižewskij (ed.), Pampaedia. Lateinischer Text und deutsche Übersetzung, 2nd edn., Quelle \& Meyer, Heidelberg. 
EKD, 2006, Erklärung des Rates der Evangelischen Kirche in Deutschland (EKD) aus Anlass der Ratspräsidentschaft der Bundesrepublik Deutschland in der Anlass der Ratspräsidentschaft der Bundesrepublik Deutschland in der
Europäischen Union. 29. Dezember 2006, viewed 30 October 2015, from http:// Europäischen Union. 29. Dezember

Herder, J.G., 1968, 'Journal meiner Reise im Jahr 1769', in C. Menze (ed.), Johann Gottfried Herder. Humanität und Erziehung, pp. 5-94, Schöningh, Paderborn.

Jencks, C., 1972, Inequality: A reassessment of the effect of family and schooling in America, Basic Books, New York.

Korczak, J., 2007, in S. Joseph (ed.), Loving every child. Wisdom for parents, Algonquin Chapel Hill, NC.

Koselleck, R., 1990, 'Einleitung - Zur anthropologischen und semantischen Struktur der Bildung', in R. Koselleck (ed.), Bildungsbürgertum im 19. Jahrhundert. Teil II: Bildungsgüter und Bildungswissen, pp. 11-46, Klett-Cotta, Stuttgart.

Luther, M., 1982a, 'An die Ratsherrn aller Städte deutschen Landes, dass sie christliche Schulen aufrichten und halten sollen', in K. Bornkamm \& G. Ebeling (eds.), Martin Luther, Ausgewählte Schriften, vol. 5, pp. 27-53, Insel, Frankfurt/M, 40-72 (WA 15).

Luther, M., 1982b, 'Eine Predigt Martin Luthers, dass man Kinder zur Schule halten solle', in, K. Bornkamm \& G. Ebeling (eds.), Martin Luther, Ausgewählte Schriften, vol. 5, WA 30,2, pp. 90-132, 517-588, Insel, Frankfurt/M

Meister Eckhart., 1963, 'Das Buch der göttlichen Tröstung', in J. Quint (ed.), Meister Eckharts Traktate (Meister Eckhart, Die deutschen und lateinischen Werke, vol. 5) pp. 471-497, Kohlhammer, Stuttgart.

Melanchthon, P., 1989, in G.R. Schmidt (ed.), Glaube und Bildung. Texte zum christlichen Humanismus. Lateinisch/Deutsch, Reclam, Stuttgart.
Nussbaum, M., 2006, Frontiers of Justice: Disability, Nationality, Species Membership, The Belknap Press of Harvard University Press, Cambridge, MA

Nussbaum, M., 2011, Creating capabilities: The human development approach, The Belknap Press of Harvard University Press, Cambridge, MA.

OECD, 2001, Knowledge and skills for life. First Results from the OECD Programme for International Student Assessment (PISA) 2000, OECD, Paris.

Schweitzer, F., 2011, Menschenwürde und Bildung. Religiöse Voraussetzungen der Pädagogik in evangelischer Perspektive, TVZ, Zürich.

Schweitzer, F., 2013, Das Recht des Kindes auf Religion, New Edition, Gütersloher Gütersloh.

Schweitzer, F., 2014a, Bildung, Neukirchener, Neukirchen-Vluyn.

Schweitzer, F., 2014b, Interreligiöse Bildung. Religiöse Vielfalt als Herausforderung und Chance, Gütersloher, Gütersloh.

Schweitzer, F., (2016) Das Bildungserbe der Reformation, Gütersloher, Gütersloh

Schwöbel, C., 2003, 'Toleranz aus Glauben. Identität und Toleranz im Horizont religiöser Wahrheitsgewissheiten', in C. Schwöbel (ed.), Christlicher Glaube im Pluralismus. Studien zu einer Theologie der Kultur, pp. 217-244, Siebeck, Tübingen.

Sen, A., 2009, The Idea of Justice, The Belknap Press of Harvard University Press, Cambridge, MA

Tröhler, D., 2011, Languages of education. Protestant legacies, national identities, and global aspirations, Routledge, New York. 